\section{Creative subversion}

\author{
John Launer
}

During my time in the British National Health Service, I have lived through so many reorganisations that I have literally lost count. When I first started out as a general practitioner (GP) around thirty years ago, my work was supervised by a Family Practitioner Committee. In time, this was replaced by a Family Health Services Authority. That was superseded by a Primary Care Group and then a Primary Care Trust. These were abolished quite recently, so that the profession is now supervised by Clinical Commissioning Groups. I also held a part-time job in secondary care and worked in a place that was initially called a Clinic, then a Trust, and is now a Foundation Trust. The health service itself was originally run by a Department of Health and Social Security, until it split and became a Department of Health, later passing over responsibility in fairly rapid succession to a NHS Executive and then an NHS Commissioning Board, which now calls itself NHS England.

I have left out several other reorganisations, including local mergers and de-mergers, and some that were too brief to be worth a mention. However, I am sure you will get the general picture. All of this has been accompanied by similar changes in the various regulators, in education and training, and by hundreds of reconfigurations in local services, with hospitals and departments combining or splitting off from each other. Fashions for working in different ways have also come and gone - and in some cases come back again. For example, at the beginning of my career in general practice, we had a large multi-disciplinary team in our practice. We worked alongside a variety of other professions including nurses and midwives. Later, these teams were disbanded and the non-medical professions became attached to localities instead. The fashion has now swung back again and multi-disciplinary teams are in favour once more. The pendulum has also swung back and forth in relation to small community hospitals, ward matrons, health visiting and a whole variety of other services.

Correspondence to Dr John Launer, Faculty Development, Health Education England, Stewart House, 32 Russell, London WC1B 5DN, UK: john.launer@nwl.hee.nhs.uk
Observing clinicians and managers down the years as they have adjusted to these changes, I have noticed how they respond in different ways. There are always some people who embrace every reorganisation with enthusiasm. When each one comes around, they express a conviction that it will be effective, definitive, and finally solve all the problems it was designed to address (even if these are the same problems that previous reorganisations were meant to solve). When new business cards arrive, the enthusiasts beam with pleasure and pride at their revised job titles. They are happy to speak in the rhetoric of the moment, whatever it is: central control or localism, expansion or efficiency savings, or the merits of private or public funding. Other colleagues feel the opposite way. Each time new stationery arrives in their offices, they talk about the unconscionable waste of money that has gone into shredding the former stock and replacing it with a different letterhead and a new logo. They cite research showing how health service reorganisations are rarely piloted, carry massive transactional costs, and do not achieve their intended objectives. ${ }^{1}$ They point out that large scale changes are inherently doomed to failure because complex adaptive systems like the NHS will always behave unpredictably. ${ }^{2}$

\section{DIFFERENT ATTITUDE}

As well as the enthusiasts and the pessimists, there are people at all levels of an organisation who adopt a quite different attitude. I call it 'creative subversion'. People with this attitude are careful not to go overboard in praising the new order - but they also avoid declaring that we have finally reached the end of civilisation as we know it. They accept that organisations are subject to irrational forces outside the control of anyone within them. They recognise that the politicians at the top always want to make their mark, usually take a short-term electoral view, and are often guided by ambition, vanity or greed more than by evidence or reason. They know there is no point in confronting or challenging the system overtly, because power is usually stacked against people wanting to preserve the 'status quo', and outright conflict is likely to end in the destruction of valuable services. Instead, they focus on the unchanging realities of the health service: patients will always come through our doors seeking help for their problems, and they need to be protected from the noise and turmoil of politics. Such people also recognise that organisations in themselves may not function intelligently, but this should not prevent individuals within them trying to do so. ${ }^{3}$

People who use creative subversion continue to do whatever was worthwhile previously, but adapt this to fit the new circumstances. They remain confident that even the most perverse and irrational changes will create openings for sensible innovation, even if this happens by accident. They devise ways of meeting ill-conceived targets and directives, in a way that also produces real benefits. They sit quietly through committee meetings, waiting for the odd moment during all the posturing and point-scoring when they can make a case for doing something sensible and practical. They rebrand their services to fit the fashionable jargon and current mission statement, while essentially leaving them unchanged. Although this may all sound manipulative, I do not think it is: creative subversion does involve a certain amount of opportunism and cunning, but not in the interests of personal advancement. The people who practise it rarely claim credit for their successes.

Constant organisational change is inevitable. In reality, governments will never stop meddling in the health service, or pulling apart what their predecessors left behind. Every change will continue to be heralded with a grandiose fanfare. Some of these changes will no doubt bring about a few modest benefits, but many will end in muddle or disappointment, as they so often have done in the past. There will always be a group of people who neither celebrate nor try to challenge reorganisations, but try to find ways of subverting them creatively. They help their organisations to meet their declared aims, although not by the means that others will necessarily appreciate or even understand. Ultimately, I suspect every organisation depends on such people, and on creative subversion, in order to survive.

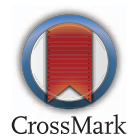

To cite Launer J. Postgrad Med J 2015;91:58.

Postgrad Med J 2015;91:58.

doi:10.1136/postgradmedj-2014-133157

\section{REFERENCES}

1 Ham C. Lessons from the past decade for future health reforms. BMJ 2009;339:pb4372

2 Chapman J. Systems failure: Why governments must learn to think differently. London, Demos, 2004 http://www.demos.co.uk/files/systemfailure2.pdf (accessed 22 November 2014)

3 Alvesson M, Spicer A. A stupidity-based theory of organizations. J Management Studies. 2012;49:1194-1120. 